\title{
Vitamin D3 effect on Albuminuria in Type 2 Diabetes Mellitus patients in Northern Andhra Pradesh, India
}

\author{
Sreedevi P. ${ }^{1}$, T. Rao V. ${ }^{2 *}$, Annaji B. ${ }^{3}$, Sudheer K. ${ }^{4}$ \\ DOI: https://doi.org/10.17511/ijmrr.2020.i04.06 \\ 1 Sreedevi P., Assistant Professor, Department of General Medicine, Great Eastern Medical School and Hospital, Srikakulam, Andhra \\ Pradesh, India. \\ 2* Venugopal T. Rao, Assistant Professor, Department of General Medicine, Great Eastern Medical School and Hospital, Srikakulam, Andhra \\ Pradesh, India. \\ ${ }^{3}$ Annaji B., Assistant Professor, Department of General Medicine, Great Eastern Medical School and Hospital, Srikakulam, Andhra Pradesh, \\ India. \\ ${ }^{4}$ Sudheer K., Professor, Department of General Medicine, Great Eastern Medical School and Hospital, Srikakulam, Andhra Pradesh, India.
}

Introduction: Vitamin D deficiency is a common disorder in diabetic patients and may be a risk factor for the progression of diabetic nephropathy. The present study aimed to assess the effects of a large dose of parenteral. Vitamin D on 24 hours albuminuria in T2DM patients. Methods: This prospective single-center study included 80 vitamin $D$ deficient $[25(\mathrm{OH}) \mathrm{D}<50 \mathrm{nmol} / \mathrm{l}]$ T2DM patients with an adequate glycemic control (HbA1c $<7.0 \%$ ). Without any changes in antihyperglycemic or antihypertensive drugs, these patients were given a single high dose (600000 IU) of parenteral Vitamin D3. Then the changes in Vitamin D levels and 24 hours albuminuria were seen on follow up at 3 months. Results: Vitamin D3 supplementation improved 24 hours albuminuria. In the present study, Twenty-four-hour urinary albumin excretion decreased from $210.4 \pm 101.2$ to $204.6 \pm 104.5$. In males, it changed from $221.8 \pm 99.7$ to $216.1 \pm 100.3$ and in females, it changed from $192.3 \pm 108.5$ to $186.7 \pm 113.1$. There was a negative association of albuminuria with Vit $D$ levels in the present study. Conclusion: Vitamin D3 supplementation significantly reduces 24-hour urinary albumin excretion in T2DM patients with Vitamin D3 deficiency.

Keywords: Albuminuria, RAS -Renin-Angiotensin System, T2DM-Type 2 Diabetes Mellitus, Vitamin $\mathrm{D}$

Corresponding Author

Venugopal T. Rao, Assistant Professor, Department of General Medicine, Great Eastern Medical School and Hospital, Srikakulam, Andhra Pradesh, India. Email: docvenu7@gmail.com
How to Cite this Article

To Browse

Sreedevi P., Venugopal T. Rao, Annaji B., Sudheer K., Vitamin D3 effect on Albuminuria in Type 2 Diabetes Mellitus patients in Northern Andhra Pradesh, India. Int J Med Res Rev. 2020;8(4):320-325.

Available From

https://ijmrr.medresearch.in/index.php/ijmrr/article/ view/1198

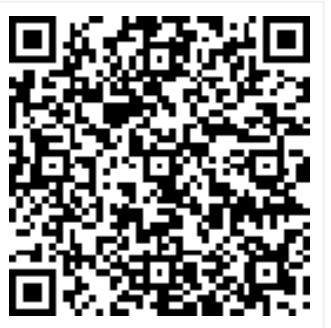

Manuscript Received 2020-06-07

Conflict of Interest No
Review Round 1 2020-06-23

Funding $\mathrm{Nil}$
Review Round 2 2020-07-15

Ethical Approval Yes
Review Round 3

Plagiarism X-checker $8 \%$
Accepted 2020-08-25

Note

(C) 2020 by Sreedevi P., Venugopal T. Rao, Annaji B., Sudheer K. and Published by Siddharth Health Research and Social Welfare Society. This is an Open Access article licensed under a Creative Commons Attribution 4.0 International License https://creativecommons.org/licenses/by/4.0/ unported [CC BY 4.0]. 


\section{Introduction}

Diabetic nephropathy is the leading cause of chronic renal disease and a major cause of cardiovascular mortality. Diabetic nephropathy is staged based on albuminuria and it is a marker for kidney injury [1].

In the pathogenesis of diabetic nephropathy, multiple pathways are engaged and the intrarenal RAS is activated [2].

Vitamin D3 negatively regulates the reninangiotensin system (RAS) as it suppresses renin biosynthesis [3].

Therefore constant low vitamin D levels can worsen renal injury in diabetic patients. Vitamin $D$ is vital for maintaining podocyte health, preventing epithelial-to-mesenchymal transformation, and suppressing inflammation [4].

Replacement with pharmacologic dosages of vitamin D receptor agonists has consistently shown a reduction in albuminuria [5] and glomerular inflammation and decreases in the renal fibrosis progression [6]. Emerging evidence in patients with nephropathy shows that vitamin D

Can reduce albuminuria even in the presence of angiotensin-converting enzyme inhibition [7]. In addition to reducing proteinuria, Vitamin $D$ reduces insulin resistance [8], blood pressure, inflammation, and preserves podocyte loss, providing biologic plausibility to the notion that the optimum Vitamin D levels are renoprotective $[9,10]$.

The present study aims to evaluate the effect of Vitamin $D$ in reducing albuminuria in type 2 diabetic patients with Vit D deficiency.

\section{Methods}

Study design:Prospective cohort study over a period of two years

Study setting: Department of Medicine, Great Eastern Medical School, and Hospital, Srikakulam, Andhra Pradesh over a period of two years from June 2018 to June 2019.

Inclusion criteria: All Type 2 diabetic patients who fulfill the following were included in the study.

01. Adequate Glycemic Control (Hba1c < 7).

02. Albuminuria ( $>30 \mathrm{mg} / 24$ hours).

03. Vitamin D Deficiency ( $<50 \mathrm{nmol} / \mathrm{l})$.

\section{Exclusion criteria}

01. Uncooperative patients or unwilling to give informed written consent.

02. Vit D or Calcium supplements consumption in the previous 3 months.

Participants: 80 consecutive Type 2 Diabetes Mellitus patients who presented to our department and fulfilled the inclusion criteria.

Statistical method: Statistical analyses were performed using SPSS 20. The difference in mean levels of vitamin $\mathrm{D}$ and albuminuria before and after treatment with parenteral vitamin D were determined by paired samples T-test. Results were considered significant with a P-value of less than 0.05 .

The study was approved by the ethics committee of the institute. 80 patients of T2DM with Vitamin D deficiency and adequate glycemic control were taken into study. Patients fulfilling the inclusion criteria were apprised of the type of study being carried out and their written consent was obtained. Vitamin $D\{25(\mathrm{OH}) \quad D\}$ and 24 hours urinary albumin levels were obtained at the baseline. One single dose 600000-unit vitamin D3 was given intramuscularly and changes in 24 hours albuminuria were seen on follow up at 3 months.

\section{Results}

The study included a total of 80 vitamin $\mathrm{D}$ deficient [25(OH) D $<50 \mathrm{nmol} / \mathrm{l}]$ T2DM patients with adequate glycemic control. 50 out of 80 participants $(62.5 \%)$ were above 50 years of age.

After supplementation with a single high dose (600000 IU) of parenteral Vitamin D3, 25(OH) D levels increased from $32.94 \pm 3.84$ to $57.21 \pm 4.84$ $\mathrm{nmol} / \mathrm{l}$. In males, it improved from $34.68 \pm 4.08$ to $58.04 \pm 4.86 \mathrm{nmol} / \mathrm{l}$ and in females from $32.44 \pm$ 3.94 to $56.92 \pm 4.72 \mathrm{nmol} / \mathrm{l}$ (Table 1 ).

Table-1: Vitamin D levels in all patients before and after supplementation.

\begin{tabular}{|l|l|l|}
\hline \multirow{2}{*}{ Variables } & \multicolumn{2}{|c|}{ Mean \pm SD } \\
\cline { 2 - 3 } & Vit D (basal) & Vit D ( After 3 months ) \\
\hline All Cases & $32.94 \pm 3.84$ & $57.21 \pm 4.84$ \\
\hline Males & $34.68 \pm 4.08$ & $58.04 \pm 4.86$ \\
\hline Females & $32.44 \pm 3.94$ & $56.92 \pm 4.72$ \\
\hline
\end{tabular}

Twenty-four-hour urinary albumin excretion decreased from $210.4 \pm 101.2$ to $204.6 \pm 104.5$. In males, it changed from $221.8 \pm 99.7$ to $216.1 \pm$ 
100.3 and in females it changed from $192.3 \pm$ 108.5 to $186.7 \pm 113.1$ (Table 2 ).

\section{Table-2: 24 hours of albuminuria levels in all patients before and after vitamin D supplementation.}

\begin{tabular}{|l|l|l|}
\hline \multirow{2}{*}{ Variables } & \multicolumn{2}{|c|}{ Mean \pm SD } \\
\cline { 2 - 3 } & Albumin (basal) & Albumin ( After 3 months) \\
\hline All Cases & $210.4 \pm 101.2$ & $204.6 \pm 104.5$ \\
\hline Males & $221.8 \pm 99.7$ & $216.1 \pm 100.3$ \\
\hline Females & $192.3 \pm 108.5$ & $186.7 \pm 113.1$ \\
\hline
\end{tabular}

\section{Discussion}

Diabetic nephropathy is the most common cause of chronic kidney disease and end-stage renal disease, about $30 \%$ to $35 \%$ of dialysis patients have diabetes [11]. Diabetes is also the most common cause of renal replacement therapy requirements, in the United States [12].

Nephropathy is the serious complication of diabetes, defined by the development of proteinuria. Proteinuria is the main predictor of chronic kidney disease progression and it is now recognized as the first therapeutic target in the management of chronic kidney disease [13-17]. Drugs that block the renin-angiotensin-aldosterone system (ARBs) are effective in reducing proteinuria and slowing down the progression of the disease. ARBs are the first step in renoprotective antiproteinuric treatment. However their antiproteinuric effect is usually suboptimal and residual proteinuria continues to be a target for treatment, with additional renoprotective agents.

Clinically, many drugs have been tested to reduce residual proteinuria, and others are being tested. Growing evidence supports a potential role for vitamin $D$ receptor (VDR) activation in reducing proteinuria. Vitamin $D$ deficiency is highly prevalent in patients with chronic kidney disease even in the early stages [18-23]. In several studies, vitamin D deficiency is related to albuminuria, lower glomerular filtration rate and chronic kidney disease progression [18, 20, 24-27], Vitamin D metabolites inhibit the renin-angiotensin system and prevent the glomerulosclerosis. Vitamin D also decreases insulin resistance and decreases blood pressure as well $[28,29]$.

Recently some studies were carried out regarding the effect of Vitamin D supplementation on reducing proteinuria in diabetic patients. However, the results of these studies are controversial. Therefore, the
Current study aimed to evaluate the effect of Vitamin $D$ in reducing proteinuria in type 2 diabetic patients with Vitamin D deficiency. Out of 80 diabetic patients included in the study, 50 (62.5\%) were above 50 years of age. This is by the epidemiological evidence of hypovitaminosis $D$ being more prevalent in the elderly [30] because they produce $75 \%$ less cutaneous vitamin D3 than young adults. After supplementation with parenteral Vitamin D3, circulating levels of 25-hydroxy vitamin $D$ were adequate in patients at follow up. So cholecalciferol via intramuscular route has effective and immediate response resulting in improved levels. There was a significant decrease in urinary albumin excretion on the follow up after Vitamin D was replenished.

Ahmadi [31] et al, in a clinical trial on diabetic patients with diabetic nephropathy and Vitamin D deficiency, found that Vitamin $D$ prescription for three months had no effect on decreasing proteinuria. Kim [32] et al in the study on 63 diabetic patients with nephropathy and low Vitamin D levels found that repletion with cholecalciferol could decrease albuminuria. They concluded that dietary Vitamin $D$ in patients with diabetic nephropathy may have a beneficial effect in delaying the progression of the disease. Ali Momeni [33] et al randomly enrolled 60 diabetic patients with proteinuria and Vitamin $D$ deficiency or insufficiency in two equal groups. They saw that there was no difference between Vitamin $D$ level in the case and control group at the beginning of the study, however, at the end of the study Vitamin D levels were significantly higher in the case group.

There was no difference in proteinuria between the case and control group at the beginning and the end of the study, while a significant difference between the changes of proteinuria before and after the study were seen in two groups. Bonakdaran [34] et al, found a significant correlation between microalbuminuria and vitamin D deficiency. Therapy with calcitriol had a beneficial effect on the albumin excretion rate, although this change was not significant. De Zeeuw [35] et al, in a study on diabetic patients, showed that $2 \mathrm{mg} /$ day of paricalcitol also of rennin-angiotensin aldosterone blockers, could decrease proteinuria. Molina P [36] et al, conducted a study on nondialysis chronic kidney disease patients with albuminuria, low vitamin D, and high parathyroid hormone levels. They found that cholecalciferol administration led to a significant rise in mean vitamin D levels and 
Urinary albumin-to-creatinine ratio significantly decreased at 6 months in the cholecalciferol group, and there was no change in the control group. Huang [5] et al, in a study, found that deficiency of Vitamin D was associated with microalbuminuria and administration of cholecalciferol significantly decreased albuminuria in the early stages of treatment. They concluded that conventional doses of cholecalciferol may have antiproteinuric effects on diabetic patients. Agarwal [37] et al, conducted a study in patients with residual proteinuria and stage 2-4 chronic kidney disease (CKD). They found a significant decrease in proteinuria in patients treated with paricalcitol compared with the control group, after 24 weeks of treatment. The authors concluded that the antiproteinuric effect of paricalcitol is a potential pharmacological action that requires further investigation. Fishbane [38] et al published a study comparing paricalcitol with placebo in patients with stage 2-3 CKD, over a follow-up period of six months. The decrease in the urine protein to creatinine ratio was significant in the paricalcitol group compared placebo group. Liu [39] et al found in a study of 50 patients with IgA nephropathy and residual proteinuria $>0.8 \mathrm{~g} /$ day that patients receiving calcitriol twice weekly had a significant decrease in proteinuria of compared with placebo, after 48 weeks of follow-up. In the National Health and Nutrition Examination Survey (NHANES III) [40], it was found that higher proportions of individuals with nephropathy have vitamin $D$ deficiency than individuals without nephropathy. This suggests that optimum vitamin D levels should be maintained to prevent albuminuria and diabetic nephropathy. The present results were similar to most of the available studies in the literature. Thus it can be concluded that the prescription of Vit $D$ in diabetic patients with nephropathy and Vit D deficiency may decrease proteinuria. The main limitation of this study is the sample size. Because of the sample size, this study can't be attributed to all the population. More such studies have to be done for a better outcome.

\section{Conclusion}

The findings of the present study have potentially important public health implications as vitamin D supplementation can ameliorate albuminuria in type 2 diabetes which is the major cause of end-stage renal disease. This study encourages the design and conduct of studies that further explore the roles of Vitamin $D$ in the nephropathy of T2DM patients for longer durations of follow up.

\section{What does the study add to the existing knowledge}

In the current study, it is found out that Vitamin D3 supplementation significantly reduces 24-hour urinary albumin excretion in T2DM patients with Vitamin D3 deficiency. Hence more studies have to be done with a good sample size and longer duration of follow up to confirm this.

\section{Author's contribution}

Dr. P. Sreedevi: Manuscript preparation

Dr. T. Venugopal Rao: Formulated the aims and objective of the study

Dr. B. Annaji: Data collection

Dr. K. Sudheer: Data analysis

\section{Reference}

01. Gross JL, De Azevedo MJ, Silveiro SP, Canani LH, Caramori ML, Zelmanovitz T. Diabetic nephropathy- diagnosis, prevention, and treatment. Diabetes Care. 2005;28(1)164-176. [Crossref]

02. Zhang Z, Zhang Y, Ning G, Deb DK, Kong J, Li YC. Combination therapy with AT1 blocker and vitamin D analog markedly ameliorates diabetic nephropathy- blockade of compensatory renin increase. Proc Natl Acad Sci USA. 2008;105(41)15896-15890.

[Crossref]

03. Li YC, Qiao G, Uskokovic M, Xiang W, Zheng W, Kong J, et al. Vitamin D- a negative endocrine regulator of the reninangiotensin system and blood pressure. J Steroid Biochem Mol Biol. 2004;89-90(1-5)387-392.

[Crossref]

04. Sonneveld R, Ferrè S, Hoenderop JG, Dijkman $\mathrm{HB}$, Berden $\mathrm{JH}$, Bindels RJ, et al. Vitamin D Down- Regulates TRPC6 Expression in Podocyte Injury and Proteinuric Glomerular Disease. Am J Pathol. 2013;182(4)1196-1204.

[Crossref]

05. Huang Y, Yu H, Lu J, Guo K, Zhang L, Bao Y, et al. Oral supplementation with cholecalciferol 800 IU ameliorates albuminuria in Chinese type 2 diabetic patients with nephropathy. PloS One. 2012;7(11)e50510.

[Crossref] 
06. Rüster C, Wolf G. Renin-angiotensin-aldosterone system and progression of renal disease. J Am Soc Nephrol. 2006;17(11)2985-2991.

[Crossref]

07. Zhang Y, Kong J, Deb DK, Chang A, Li YC. Vitamin D Receptor Attenuates Renal Fibrosis by Suppressing the Renin-Angiotensin System. J Am Soc Nephrol. 2010;21(6)966-973.

[Crossref]

08. Pittas AG, Lau J, Hu FB, Dawson-Hughes B. The role of vitamin $D$ and calcium in type 2 diabetes- A systematic review and metaanalysis. J Clin Endocrinol Metab. 2007;92(6)2017-2029.

[Crossref]

09. G Klaus. Renoprotection with vitamin D- specific for diabetic nephropathy. Kidney Int. $2008 ; 73(2) 141-143$.

[Crossref]

10. Diaz VA, Mainous AG, Carek PJ, Wessell AM, Everett $C J$. The association of vitamin $D$ deficiency and insufficiency with diabetic nephropathy- implications for health disparities. J Am Board Fam Med. 2009;22(5)521-527. [Crossref]

11. Collins AJ, Kasiske B, Herzog C, Chavers B, Foley R, Gilbertson $D$, et al. Excerpts from the United States Renal Data System 2006 Annual Data Report. Am J Kidney Dis. 2007;49(1)A6A7.

[Crossref]

12. Jacob AN, Khuder $S$, Malhotra N, Sodeman $T$, Gold JP, Malhotra D, et al. Neural network analysis to predict mortality in end-stage renal disease- application to United States Renal Data System. Nephron Clin Pract. 2010;116(2)c148c158.

[Crossref]

13. KDIGO. Clinical Practice Guideline for the Evaluation and Management of Chronic Kidney Disease. Kidney Int Suppl. 2013;3(1)1-150. [Crossref]

14. Abbate M, Zoja C, Remuzzi G. How does proteinuria cause progressive renal damage. J Am Soc Nephrol. 2006;17(11)2974-2784. [Crossref]

15. Palmer BF. Proteinuria as a therapeutic target in patients with chronic kidney disease. Am J Nephrol. 2007;27(3)287-293.

[Crossref]
16. Ruggenenti P, Perna A, Mosconi L, Pisoni $R$, Remuzzi G. Urinary protein excretion rate is the best independent predictor of ESRF in nondiabetic proteinuric chronic nephropathies. Kidney Int. 1998;53(5)1209-1216.

[Crossref]

17. Taal MW, Brenner BM. Predicting initiation and progression of chronic kidney diseaseDeveloping renal risk scores. Kidney Int. 2006;70(10)1694-1705.

[Crossref]

18. Górriz JL, Molina P, Bover J, Barril G, Martín-de Francisco ÁL, Caravaca F, et al. Characteristics of bone mineral metabolism in patients with stage 3-5 chronic kidney disease not on dialysisresults of the OSERCE study. Nefrología. $2013 ; 33(1) 46-60$.

[Crossref]

19. Mehrotra R, Kermah D, Budoff M, Salusky IB, Mao SS, Gao YL, et al. Hypovitaminosis D in chronic kidney disease. Clin J Am Soc Nephrol. 2008;3(4)1144-1151.

[Crossref]

20. Levin A, Bakris GL, Molitch $M$, Smulders $M$, Tian J, Williams LA, et al. Prevalence of abnormal serum vitamin D, PTH, calcium, and phosphorus in patients with chronic kidney disease- results of the study to evaluate early kidney disease. Kidney Int. 2007;71(1)31-38.

[Crossref]

21. LaClair RE, Hellman RN, Karp SL, Kraus $M$, Ofner S, Li Q, Graves KL, Moe SM. Prevalence of calcidiol deficiency in CKD- a cross-sectional study across latitudes in the United States. Am J Kidney Dis. 2005;45(6)1026-1033.

[Crossref]

22. González EA, Sachdeva A, Oliver DA, Martin KJ. Vitamin $D$ insufficiency and deficiency in chronic kidney disease. Am J Nephrol. 2004;24(5)503510.

[Crossref]

23. Zhang Z, Sun L, Wang Y, Ning G, Minto AW, Kong J, et al. Renoprotective role of the vitamin $D$ receptor in diabetic nephropathy. Kidney Int. $2008 ; 73(2) 163-171$.

[Crossref]

24. Al-Badr W, Martin KJ. Vitamin D and kidney disease. Clin J Am Soc Nephrol. 2008;3(5)15551560.

[Crossref] 
25. Looker AC, Dawson-Hughes B, Calvo MS, Gunter EW, Sahyoun NR. Serum 25-hydroxyvitamin D status of adolescents and adults in two seasonal subpopulations from NHANES III. Bone. $2002 ; 30(5) 771-777$.

[Crossref]

26. Alvarez JA, Law J, Coakley KE, Zughaier SM, Hao L, Shahid Salles K, et al. High- dose cholecalciferol reduces parathyroid hormone in patients with early chronic kidney disease- a pilot, randomized, double-blind, placebocontrolled trial. Am J Clin Nutr. 2012;96(3)672679.

[Crossref]

27. Marckmann $\mathrm{P}$, Agerskow $\mathrm{H}$, Thineshkumar $\mathrm{S}$ et al. Randomized controlled trial of cholecalciferol supplementation in chronickidney disease patients with hypovitaminosis D. Nephrol Dial Transplant. 2012;27(9)3523-3531.

[Crossref]

28. Moe SM, Saifullah A, LaClair RE, Usman SA, Yu $Z$. A randomized trial of cholecalciferol versus doxercalciferol for lowering parathyroid hormone in chronic kidney disease. Clin J Am Soc Nephrol. 2010;5(2)299-306.

[Crossref]

29. Schwarz U, Amann K, Orth SR, Simonaviciene A, Wessels S, Ritz E. Effect of 1,25 (OH)2 vitamin D3 on glomerulosclerosis in subtotally nephrectomized rats. Kidney Int. 1998;53(6)1696-1705.

[Crossref]

30. Lips P. Vitamin D deficiency and secondary hyperparathyroidism in the elderly. Endocr Rev. $2001 ; 22(4) 477-501$.

[Crossref]

31. Molina $P$, Górriz JL, Molina MD, Peris A, Beltrán S, Kanter J, et al. The effect of cholecalciferol for lowering albuminuria in chronic kidney disease- a prospective controlled study. Nephrol Dial Transplant. 2014;29(1)97-109. [Crossref]

32. Kim MJ, Frankel AH, Donaldson $M$, Darch SJ, Pusey CD, Hill PD, et al. Oral cholecalciferol decreases albuminuria and urinary TGF-beta1 in patients with type 2 diabetic nephropathy on established renin-angiotensin-aldosterone system inhibition. Kidney Int. 2011;80(8)851860.

[Crossref]
33. Ahmadi N, Mortazavi M, Iraj B, Askari G. Whether vitamin D3 is effective in reducing proteinuria in type 2 diabetic patients. J Res Med Sci. 2013;18(5)374-377.

[Crossref]

34. Momeni A, Mirhosseini $M$, Kabiri $M$, Kheiri $S$. Effect of vitamin $D$ on proteinuria in type 2 diabetic patients. J Nephropathol. 2017;6(1)1014.

[Crossref]

35. Bonakdaran S, Hami M, Hatefi A. The effects of calcitriol on albuminuria in patients with type-2 diabetes mellitus. Saudi J Kidney Dis Transpl. 2012;23(6)1215-1220.

[Crossref]

36. De Zeeuw D, Agarwal R, Amdahl M, Audhya P, Coyne D, Garimella T, et al. Selective vitamin D receptor activation with paricalcitol for reduction of albuminuria in patients with type 2 diabetes (VITAL study)- a randomised controlled trial. Lancet. 2010;376(9752)1543-1551.

[Crossref]

37. Agarwal R, Acharya M, Tian J, Hippensteel RL, Melnick JZ, Qiu P, et al. Antiproteinuric effect of oral paricalcitol in chronic kidney disease. Kidney Int. 2005;68(6)2823-2828. [Crossref]

38. Fishbane $S$, Chittineni $H$, Packman M, Dutka $P$, Ali N, Durie N. Oral paricalcitol in the treatment of patients with CKD and proteinuria- a randomized trial. Am J Kid Dis. 2009;54(4)647652.

[Crossref]

39. Liu LJ, Lv JC, Shi SF, Chen YQ, Zhang H, Wang HY. Oral calcitriol for reduction of proteinuria in patients with IgA nephropathy- a randomized controlled trial. Am J Kidney Dis. 2012;59(1)6774.

[Crossref]

40. Scragg $R$, Sowers $M$, Bell C. Serum 25hydroxyvitamin $D$, diabetes, and ethnicity in the Third National Health and Nutrition Examination Survey. Diabetes Care. 2004;27(12)2813-2818. [Crossref] 